\title{
Produktivitas Puyuh yang Diberi Ransum Suplementasi Berbagai Level Tepung Cangkang Telur Itik
}

\section{(Quail Productivity were Given with Supplementation Diets of Various Level of Duck Egg Shells Powder)}

\author{
Gilang Rafi Abyansyah*, Suhardi, Eudia Christina Wulandari \\ Program Studi Peternakan, Fakultas Peternakan, Universitas Boyolali \\ Jl. Pandanaran No.405, Boyolali \\ *Penulis Korespondensi : gilangrafi10@gmail.com
}

\begin{abstract}
ABSTRAK
Penelitian ini bertujuan untuk mengetahui sejauh mana pengaruh pemberian berbagai level suplementasi tepung cangkang telur itik di dalam ransum burung puyuh (Coturnix-coturnix japonica) sebagai bahan pakan sumber kalsium terhadap produktivitas burung puyuh. Penelitian ini menggunakan 82 ekor burung puyuh betina berumur 49 hari dan pengambilan data hingga umur 90 hari. Rancangan percobaan menggunakan rancangan acak lengkap (RAL) yang terdiri dari 4 perlakuan dan 5 ulangan. Perlakuan tersebut adalah tepung cangkang telur itik dengan beberapa level pemberian ransum, yaitu $\mathbf{P} 0=0 \%$ tepung cangkang telur itik, $\mathrm{P} 1=\mathbf{0}, 25 \%$ tepung cangkang telur itik $+99,75 \%$ pakan komersil, $\mathrm{P} 2=0,50 \%$ tepung cangkang telur itik $+99,5 \%$ pakan komersil, $\mathrm{P} 3=0,75 \%$ tepung cangkang telur itik $+99,25 \%$ pakan komersil. Parameter yang diukur yaitu berat telur, berat cangkang, tebal cangkang telur, dan protein telur. Hasil Uji ANOVA menyatakan bahwa perlakuan berbeda nyata $(\mathrm{P}<0,05)$ pada produksi telur harian (QDP) dan berbeda sangat nyata $(P<0,01)$ pada berat telur. Hasil penelitian ini menunjukkan bahwa tepung cangkang telur itik pada level $0,5 \%$ dapat dimanfaatkan secara optimal untuk mempengaruhi produksi telur harian burung puyuh dan pada level $0,25 \%$ dapat dimanfaatkan untuk mempengaruhi berat telur.
\end{abstract}

Kata kunci: burung puyuh, cangkang telur, kalsium, protein

\section{ABSTRACT}

This study aims to determine the extent of the effect from different levels of supplementation of duck egg shells powder in the diet of quail (Coturnix-Coturnix japonica) as feed material source of calcium to productivity quail. This study used 82 birds 49 days old female quail and retrieval of data up to the age of 90 days. The experimental design used completely randomized design, which consists of 4 treatments 
and 5 replications. The treatment was duck egg shell powder with some level of rationing, ie $\mathbf{P 0}=0 \%$ duck egg shell powder, $\mathrm{P} 1=0.25 \%$ duck egg shell powder $+99.75 \%$ commercial feed, $\mathrm{P} 2=\mathbf{0 . 5 0} \%$ duck egg shell powder $+\mathbf{9 9 . 5} \%$ commercial feed, $\mathrm{P} 3=\mathbf{0 . 7 5} \%$ duck egg shell powder $+99.25 \%$ commercial feed. The measured parameters ie feed consumption, calcium, protein, and the daily egg production (QDP). ANOVA test results showed that the treatment significantly different $(P<0,05)$ on daily egg production (QDP) and very significantly different $(P<0,01)$ on egg weights. Based on the results of this study indicate that duck egg shell powder at $0.5 \%$ can be used optimally to affect the daily egg production of quail and at $0,25 \%$ can be used to affect the egg weights.

Keywords: calcium, egg shell, protein, quail

\section{PENDAHULUAN}

Pengembangan aneka ternak, termasuk burung puyuh, merupakan suatu upaya untuk memaksimalkan potensi komoditas peternakan dalam penyediaan protein hewani untuk memenuhi kebutuhan masyarakat. Salah satu yang dapat dikembangkan adalah, burung puyuh untuk menghasilkan telur dan daging, karena kontribusinya relatif masih sangat kecil dibanding kontribusi dari komoditi unggas yang lainnya seperti ayam dan itik. Burung puyuh yang kita kenal saat ini terdiri atas dua jenis yaitu burung puyuh liar atau gemak dan burung puyuh hasil domestikasi/persilangan (Coturnixcoturnix japonica).

Menurut Wuryadi (2011), puyuh betina akan mulai bertelur pada umur 42 hari dan produktivitasnya dapat mencapai 250-300 butir/tahun dengan berat telur rata-rata $10 \mathrm{~g} / \mathrm{butir}$. Puyuh bertelur selama 15-18 bulan dengan puncak produksinya terjadi pada umur 3-5 bulan, dengan rata-rata produksi telur dalam satu populasi berkisar antara $78-85 \%$

Dalam proses produksi telur, burung puyuh membutuhkan asupan kalsium untuk mendukung proses pembentukan telur. Salah satu bahan pakan yang mengandung kalsium dan dapat digunakan yaitu tepung cangkang telur. Pemanfaatan tepung cangkang telur dalam ransum burung puyuh sudah dilakukan dalam penelitian sebelumnya oleh Herman (2009), pemberian tepung cangkang telur ayam ras dalam ransum burung puyuh sampai level 6\% menaikkan produksi telur burung puyuh. kandungan kalsium dalam tepung cangkang telur ayam ras sebesar 6,41\% (Yonata et al., 2017). Tujuan dilakukannya penelitian ini adalah untuk mengetahui pengaruh pemberian ransum suplementasi berbagai level tepung cangkang telur itik dalam ransum terhadap produktivitas burung puyuh.

\section{MATERI DAN METODE}

Materi yang digunakan di dalam penelitian yaitu burung puyuh umur 1 hari (DOQ) sebanyak 82 ekor berkelamin betina. Pakan untuk DOQ adalah pakan komersil (BR crumble) untuk burung puyuh umur 1 hingga 49 hari dan PP-3 merk "Wonokoyo" yang dicampur dengan bahan perlakuan berupa tepung cangkang telur itik (TCTI) untuk burung 
puyuh umur 49 hari dengan 4 level suplementasi yaitu sebesar $0 \%, 0,25 \%$, $0,5 \%$, dan $0,75 \%$. Peralatan yang digunakan berupa kandang baterai, tempat ransum dan minum. timbangan digital, mikrometer skrup, blender, egg tray, gelas plastik, plastik klip, pinset, stapless, kertas label, dan alat tulis. Penelitian ini dilaksanakan di kandang yang beralamat di Perum Tiara Ardi RT 009/RW 002 Desa Randusari, Teras, Boyolali. Penelitian menggunakan metode rancangan acak lengkap (RAL) dengan 4 perlakuan dan 5 ulangan dengan masing-masing ulangan terdiri dari 4-5 unit percobaan. Ransum perlakuannya adalah yaitu $\mathrm{P} 0=$ Pakan komersil PP3 merk Wonokoyo tanpa suplementasi tepung cangkang telur itik, P1 $=0,25 \%$ tepung cangkang telur itik + 99,75\% pakan komersil PP3 merk Wonokoyo, $\mathrm{P} 2=0,50 \%$ tepung cangkang telur itik + 99,5\% pakan komersil PP3 merk Wonokoyo, P3 $=0,75 \%$ tepung cangkang telur itik $+99,25 \%$ pakan komersil PP3 merk Wonokoyo.

Tabel 1. Kandungan Zat Makanan Bahan Penyusun Ransum Perlakuan

\begin{tabular}{|c|c|c|}
\hline Zat makanan & Pakan Komersil & Tepung Cangkang Telur Itik \\
\hline & \multicolumn{2}{|c|}{------------------------------ \% ------------------------------ } \\
\hline Protein Kasar & $19,38^{\mathrm{a}}$ & $0,69^{c}$ \\
\hline Lemak Kasar & $6^{\mathrm{b}}$ & - \\
\hline Serat Kasar & $5^{b}$ & - \\
\hline Abu & $12^{\mathrm{b}}$ & - \\
\hline Kalsium & $3,3^{\mathrm{b}}$ & $10,11^{\mathrm{d}}$ \\
\hline Fosfor & $0,8^{\mathrm{b}}$ & - \\
\hline Energi metabolis (kkal/kg) & $2600^{b}$ & - \\
\hline
\end{tabular}

Keterangan: a) Hasil uji di Laboratorium Ilmu Nutrisi dan Pakan Fakultas Peternakan Universitas Diponegoro, Semarang; $\left.{ }^{b}\right)$ Sumber dari PT. Wonokoyo Jaya Corporindo - pakan jadi puyuh layer umur lebih dari 7 minggu pada http://wonokoyo-toni.blogspot.com/2011/12/jenis-pakan-ternak.html diakses pada 11 Agustus 2019; c) Hasil uji di Laboratorium Pengujian "LPPT-UGM" Yogyakarta; ${ }^{\text {d) }}$ Nilai kadar kalsium tepung cangkang telur unggas tanpa perendaman (Yonata et al., 2017)

Tabel 2. Komposisi Bahan Penyusun Ransum Perlakuan

\begin{tabular}{lcccc}
\hline \multirow{2}{*}{ Bahan } & \multicolumn{4}{c}{ Perlakuan } \\
\cline { 2 - 5 } & P0 & P1 & P2 & P3 \\
\hline \multirow{2}{*}{ Pakan Pabrikan } & $--------------1 \%$ & 99,75 & 99,50 & 99,25 \\
Tepung Cangkang Telur Itik & 100 & 0,25 & 0,50 & 0,75 \\
\hline Jumlah & 0 & 100 & 100 & 100 \\
\hline
\end{tabular}

Tabel 3. Kandungan Nutrisi Ransum Perlakuan

\begin{tabular}{lcccc}
\hline \multirow{2}{*}{ Kandungan Nutrisi } & \multicolumn{4}{c}{ Perlakuan } \\
\cline { 2 - 4 } & P0 & P1 & P2 & P3 \\
\hline Protein Kasar & $----19,38$ & 19,33 & 19,28 & 19,24 \\
Lemak & 6 & 6 & 6 & 6 \\
Serat Kasar & 5 & 5 & 5 & 5 \\
Abu & 12 & 12 & 12 & 12 \\
Kalsium & 3,30 & 3,32 & 3,33 & 3,35 \\
Phospor & 0,8 & 0,8 & 0,8 & 0,8 \\
Energi Metabolis (Kkal/kg) & 2600 & 2600 & 2600 & 2600 \\
\hline
\end{tabular}




\section{HASIL DAN PEMBAHASAN}

Data hasil penelitian terhadap konsumsi ransum, produksi telur harian (QDP), umur awal bertelur, dan berat telur pada burung puyuh umur 49-90 hari tersaji pada tabel 4 .

Hasil pengamatan pemberian suplementasi TCTI hingga level 0,75\% menunjukkan berbeda tidak nyata $(\mathrm{P}<0,05)$ pada konsumsi ransum yaitu sebesar 29,01 (P0), 29,31 (P1), 29,27 (P2), dan 29,09 (P3) g/ekor/hari. Hal ini karena kandungan zat makanan terutama kandungan Energi Metabolis ransum yang diberikan pada setiap perlakuan relatif sama yaitu $2600 \mathrm{kkal} / \mathrm{kg}$, sehingga konsumsi ransum tiap perlakuan tidak jauh berbeda. Seperti yang disampaikan oleh Houndonougbo et al. (2009) bahwa konsumsi pakan yang sama pada pakan perlakuan disebabkan karena kadar energi yang hampir sama. Menurut Anggitasari et al. (2016) menyatakan bahwa faktor utama yang mempengaruhi konsumsi pakan adalah kandungan energi dalam pakan dan keadaan suhu lingkungan. Pakan dengan energi metabolis yang lebih rendah akan memacu unggas untuk mengkonsumsi pakan tambahan untuk memenuhi kebutuhan energi. Namun, data yang didapatkan menunjukkan bahwa konsumsi ransum lebih tinggi dibandingkan hasil penelitian Achmanu et al. (2011) bahwa konsumsi ransum puyuh adalah 21,05 gram/ekor/hari.

Tabel 4. Konsumsi ransum, produksi telur harian (QDP), umur awal bertelur, dan berat telur

\begin{tabular}{lcccc}
\hline \multirow{2}{*}{ Parameter } & \multicolumn{4}{c}{ Perlakuan } \\
\cline { 2 - 5 } & P0 & P1 & P2 & P3 \\
\hline Konsumsi Ransum (g/ekor/hari) & 29,01 & 29,31 & 29,27 & 29,09 \\
QDP (\%) & $81,25^{\mathrm{a}}$ & $88,75^{\mathrm{c}}$ & $91,25^{\mathrm{b}}$ & $86,00^{\mathrm{c}}$ \\
Umur Awal Bertelur (hari) & $72^{\mathrm{C}}$ & $58^{\mathrm{B}}$ & $57^{\mathrm{A}}$ & $59^{\mathrm{B}}$ \\
Berat Telur (g/butir) & $10,38^{\mathrm{A}}$ & $11,70^{\mathrm{C}}$ & $11,16^{\mathrm{B}}$ & $11,18^{\mathrm{B}}$ \\
\hline
\end{tabular}

Keterangan: Superskrip huruf kecil yang berbeda menunjukkan berbeda nyata $(\mathrm{P}<0,05)$. Superskrip huruf kapital yang berbeda menunjukkan berbeda sangat nyata $(\mathrm{P}<0,01)$

Hasil pengamatan terhadap pemberian suplementasi TCTI dalam ransum hingga level 0,75\% menunjukkan berbeda nyata $(\mathrm{P}>0.05)$ pada QDP burung puyuh fase layer umur 49-90 hari. Hasil pengamatan masing-masing sebesar 81,25\% (P0), 88,75\% (P1), 91,25\% (P2), dan $86,00 \%$ (P3). QDP paling tinggi terlihat pada burung puyuh dengan perlakuan P2 (Tabel 4) yaitu sebesar 91,25\%. Hal ini karena pakan yang digunakan pada ransum kontrol (P0) tidak diberikan suplementasi tepung cangkang telur itik sebagai salah satu sumber kalsium sebagai mineral untuk membantu produksi telur pada burung puyuh.
Pada perlakuan pemberian suplementasi TCTI dengan level pemberian sebesar $0,5 \%$ (P2) ternyata mampu membuat rataan produksi telur pada hari ke 49-90 burung puyuh lebih tinggi yaitu sebesar $91,25 \%$, daripada burung puyuh puyuh dengan pemberian suplementasi tepung cangkang telur itik pada level $0,25 \%$ (88,75\%) dan level $0,75 \% \quad(86,00 \%)$ yang hasil antara keduanya ternyata tidak berbeda nyata.

Faktor lain yang mempengaruhi QDP burung puyuh yaitu karena rataan waktu bertelur menunjukkan berbeda sangat nyata $(\mathrm{P}>0,01)$. Terlihat burung puyuh pada P2 (57 hari) umur pertama bertelurnya lebih cepat daripada burung 
puyuh P1 (58 hari) dan P3 (59 hari), sehingga pada hari ke 90 persentase produksi telur P2 $(91,25 \%)$ menjadi lebih tinggi daripada P1 $(88,75 \%)$ dan P3 $(86,00 \%)$. Selain itu, QDP yang masih belum merata juga diduga karena umur puyuh belum mencapai puncak produksi. Seperti yang disampaikan oleh Wuryadi (2011), bahwa puncak produksi puyuh petelur baru terjadi pada umur 3-5 bulan (12-20 minggu) dengan rata-rata produksi telur dalam satu populasi berkisar $78-85 \%$.

Umur bertelur pertama pada penelitian ini (P2 dengan 57 hari) lebih lambat dibandingkan dengan penelitian Masroh et al. (2014) bahwa umur pertama bertelur pada puyuh yang diberi ransum komersil adalah 47 hari. Menurut Zainudin dan Syahruddin (2012) bahwa lambatnya umur induk bertelur juga berkaitan dengan genetik puyuh yang dipelihara. Hal tersebut yang kemudian membuat perbedaan waktu bertelur antar perlakuan ikut mempengaruhi persentasi produksi telur harian (QDP).

Hasil penelitian berat telur antar perlakuan menunjukkan berbeda sangat nyata $(\mathrm{P}>0,01)$ pada $\mathrm{P} 1 \quad(11,70 \mathrm{~g} / \mathrm{butir})$ terhadap P0 (10,38 g/butir), P2 (11,16 g/butir), dan P3 (11,18 g/butir). Berat telur paling tinggi terlihat pada burung puyuh dengan perlakuan P1 (Tabel 4) yaitu (11,70 g/butir). Hal ini menunjukkan bahwa penggunaan TCTI pada level 0,25\% mampu meningkatkan berat telur burung fase layer umur 49-90 hari.

Pada burung puyuh P1, penyerapan protein oleh burung puyuh dapat terjadi secara optimal karena porsi protein dalam ransum lebih banyak daripada burung puyuh P2 dan burung puyuh P3. Sedangkan porsi protein dalam ransum P2 dan P3 semakin menurun seiring bertambahnya porsi kalsium dalam ransum dengan adanya penambahan suplementasi TCTI sebanyak $0,5 \%$ dan $0,75 \%$ (Tabel 4 ) dan mengakibatkan terbentuknya calcium binding protein $(\mathrm{CaBP})$ atau protein yang mengikat kalsium untuk diabsorbsi oleh usus.

Konsumsi protein merupakan salah satu faktor yang mempengaruhi kekentalan albumen telur, semakin kental maka telur akan semakin berat (Rahmat et al., 2016). Tugiyanti dan Iriyanti (2012) menyatakan bahwa berat kuning telur yang juga mempengaruhi berat telur dipengaruhi oleh perkembangan ovarium, berat badan, umur saat mencapai dewasa kelamin, kualitas dan kuantitas pakan, penyakit, lingkungan, dan konsumsi ransum. Proses pembentukan kuning telur menghasilkan berat kuning telur yang berebeda-beda tergantung dari kemampuan genetis masing-masing individu unggas tersebut (Yuwanta, 2010).

\section{KESIMPULAN}

Pemberian TCTI perlakuan kedua (P2 dengan level TCTI 0,50\%) mampu mengoptimakan produktifitas puyuh fase layer umur 49-90 hari berdasarkan persentase produksi telur harian (QDP) yaitu hingga $91,25 \%$ dan pada pemberian TCTI perlakuan pertama (P1 dengan level TCTI 0,25\%) mampu mempengaruhi berat telur hingga 11,70 g/butir.

\section{DAFTAR PUSTAKA}

Achmanu., Muharlien dan Salaby. 2011. Pengaruh Lantai Kandang (Rapat dan Renggang) dan Imbangan Jantan-Betina Terhadap Konsumsi Pakan, Bobot Telur, Konversi Pakan dan Tebal Kerabang Pada Burung Puyuh. Ternak Tropika. 12:1-14 
Anggitasari, S., Sjofjan, O. dan Djunaidi, I.H. 2016. Pengaruh Beberapa Jenis Pakan Komersial Terhadap Kinerja Produksi Kuantitatif dan Kualitatif Ayam Pedaging. Buletin Peternakan. 40(3):187-196.

Houndonougbo, F.M., A. Chwalibog and C.A.A.M. Chrysostome. 2009. Is the nutritional value of grains in broiler chickens' diets affected by environmental factors of soybean (Glycine max) growing and the variety of maize (Zea maize) in Benin. Livestock Research for Rural Development 21. Available at http://www/Irrd.org/Irrd21/2/cont2 012.htm. Accession date: $29^{\text {th }}$ September, 2011.

Masroh, F. K., E. Sudjarwo, E. Widodo. 2014. Pengaruh Penambahan Tepung Kulit Singkong Terfermentasi Terhadap Performans Pertumbuhan dan Umur Pertama Bertelur pada Puyuh. Laporan Penelitian.Fakultas Peternakan Universitas Brawijaya, Malang.

Rahmat, A.H., Sujana, E., dan Tanwiriah, W. 2016. Pengaruh Pemberian Tingkat Protein Dalam Ransum Terhadap Kualitas Telur Puyuh (Coturnix coturnix japonica). Fakultas Peternakan, Universitas Padjajaran, Sumedang.

Tugiyanti, E. dan N. Iriyanti. 2012. Kualitas Eksternal Telur Ayam Petelur yang Mendapat Ransum Dengan Penambahan Tepung Ikan Fermentasi Menggunakan Isolat Prosedur Antihistamin. J. Apl. Tek. Pang. 1(2).

Wuryadi, S. 2011. Buku Pintar Beternak dan Bisnis Puyuh. Agromedia Pustaka, Jakarta.

Yonata, D., Aminah, S. dan Wikanastri H. 2017. Kadar Kalsium dan
Karakteristik Fisik Tepung Cangkang Telur Unggas dengan Perendaman Berbagai Pelarut. J. Pang. \& Gizi. 7(2):82-93.

Yuwanta, T. (2010). Telur dan Kualitas Telur. Gadjah Mada University Press, Yogyakarta.

Zainudin, S. dan Syahruddin. 2012. Pemanfaatan Tepung Keong Mas sebagai Substitusi Tepung Ikan dalam Ransum Terhadap Performa dan Produksi Telur Puyuh. Laporan Penelitian. Fakultas IlmuIlmu Pertanian Universitas Negeri Gorontalo, Gorontalo. 